Modern Asian Studies 51, 3 (2017) pp. 543-576. (C) Cambridge University Press 2017 doi:10.1017/Soo26749X15000396 First published online 5 April 2017

\title{
Actualized Stigma: The historical formation of anti-Americanism in North Korea*
}

\author{
TAEWOO KIM \\ Dept. of Korean Studies, Hankuk University of Foreign Studies, \\ Republic of Korea \\ Email: peace2I@snu.ac.kr
}

\begin{abstract}
During the Open Port period and Japanese colonial period (1876-1945), Koreans generally had a positive image of the United States. This positive view of the United States held by Koreans persisted until after liberation from Japanese colonial rule in 1945 . The United States was a 'liberator' that saved the Koreans, and was viewed as 'a cooperator' with whom Korea was to solve its national task of establishing a new country. However, the concept of 'American imperialist warmonger' had begun to be promoted in North Korea from 1948-49. It was a concept advanced by the Soviet Union and the North Korean leadership. The negative image of the United States, which spread throughout North Korea from the early years of the Cold War, was merely a perplexing stigma lacking substantiated grounds. However, the experiences of the Korean War actualized the image of the United States as a 'warmonger' in the hearts of the North Korean people. Alleged indiscriminate aerial bombings, mass slaughters, sexual assaults, and arson attacks against Korean civilians became the most important reason for the expansion of intense sentiment. Anti-Americanism began to be systemized and routinized in every aspect of North Korean life after the Korean War.
\end{abstract}

\section{Introduction}

Generally, anti-Americanism, or anti-American sentiment, is an opposition to, dislike of, or hostility toward the United States of America, the American people, or the politics, culture, society, economics, or foreign policies of the United States. ${ }^{1}$ There are

* This work was supported by: the National Research Foundation of Korea (NRF) grant funded by the Korean Government (MEST) (NRF-2010-361-Aooo17); Hankuk University of Foreign Studies Research Fund.

${ }^{1}$ There is no widely agreed upon definition of the term 'anti-Americanism'. Scholarship on the topic has been largely patchy and impressionistic. For example, 
extremely diverse types of anti-Americanism in existence throughout the world. Ranging from anti-Americanism that was triggered by hostility toward specific policies or conducts of the United States government to that rejecting the liberal and capitalistic system of the United States itself, the types and entities of anti-Americanism vary greatly. Of course, the diverse types of anti-Americanism have diverse formation backgrounds and causes. For example, Peter Katzenstein and Robert Keohane suggest power imbalances, globalization, and the collision of identities as the causes of anti-Americanism. ${ }^{2}$ Paul Hollander points out the absence of an enemy due to the collapse of the Soviet Union, the exercising of military power by the United States, anti-Bush sentiment, globalization, and Islamic fundamentalism as the causes of anti-Americanism. ${ }^{3}$ Most preceding studies verify the cause of anti-Americanism in all corners of the world as centring on several characteristics that manifested throughout the world after the end of the Cold War. However, these kinds of explanations seem not to be applicable to the Korean peninsula, which can be viewed as the last vestiges of the Cold War due to the present division of its territory. This territorial division resulted from the co-occupation by the United States and the Soviet Union in the early years of the Cold War, and was strongly established by the Korean War (1950-53), which was the first international military conflict during the Cold War era.

Generally, the perception of the United States by the North and South Korean people has not changed considerably since the end of the international Cold War confrontations. As Bruce Cumings indicated, the anti-Americanism of South Koreans these days is an echo of their suppressed opposition to the United States during the Cold War period. Cumings noted that recent South Korean anti-American

Marie-France Toinet suggests that the use of the term is only fully justified if it implies systematic opposition-a sort of allergic reaction-to Americans as a whole'. Alvin Rubinstein and Donald Smith offer a broader definition of anti-Americanism as a 'hostile action or expression that becomes part and parcel of an undifferentiated attack on the foreign policy, society, culture and values of the United States'. MarieFrance, Toinet (1990), 'Does anti-Americanism exist?' in Denis Lacorne et al. (eds), The Rise and Fall of Anti-Americanism, Macmillan, London, p. 219 ; Alvin, Rubinstein and Donald, Smith (1988), Anti-Americanism in the third world, Annals (AAPSS), 497 (May), p. 35; Brendon, O'Connor (2004), A brief history of anti-Americanism: From cultural criticism to terrorism, Australian Journal of American Studies, 23(1), pp. $77-78$.

${ }^{2}$ Peter, Katzenstein and Robert, Keohane (eds) (2007), Anti-Americanisms in World Politics, Cornell University Press, New York, pp. 307-309.

${ }^{3}$ Paul, Hollander (ed.) (2004), Understanding Anti-Americanism, Ivan R. Dee, Chicago, pp. 16-23. 
sentiment just reflects disapproval of certain United States policies. It is not general antagonism against the United States. ${ }^{4}$ Although antiAmerican sentiment began to emerge in South Korea in the 1980s, it was only a temporary and partial social phenomenon that could not change essential and fundamental pro-Americanism during the Cold War era. ${ }^{5}$ Some scholars explained that this favourable attitude of South Koreans towards the United States is the legacy of anticommunism and memories of the Korean War. It produced a strong fear of the Soviet Union and North Korea and a feeling of genuine warmth towards the United States for supporting South Korea with the sacrifice of thousands of young men and millions of dollars in aid. ${ }^{6}$

This article will show that the anti-Americanism of North Korea is also closely related with the history of the Cold War, which still persists strongly in the Korean peninsula. Here, anti-Americanism in North Korea is discussed from a historical viewpoint. Anti-Americanism in North Korea has a long historical background and earlier studies about the subject achieve some consensus on its historical characteristics, but they have not attempted detailed investigation into the historical formation of anti-Americanism in North Korea. While explaining how historical experiences of the Korean War partially affected the formation of anti-Americanism in North Korea, most of the studies degrade the historical characteristics of anti-Americanism by claiming that the historical facts have been fabricated by the North Korean regime. For example, a Korean researcher who is actively publishing his studies on anti-Americanism outspokenly asserts that

\footnotetext{
${ }^{4}$ Bruce, Cumings (2003), Hanguk panmijuŭi ŭi kujojŏk kiban [Structural foundations of the anti-Americanism in South Korea], Yǒksa bip’yŏng [Critical Review of History], 62 (March), pp. 45-84.

${ }^{5}$ For example, according to the result of a public survey conducted by the Institute for Peace and Unification Studies in Seoul National University in 2013, 79.9 per cent of South Koreans regarded the United States as an 'ally', and only o.6 per cent considered the United States as a 'hostile country'. The results of a survey encompassing seven years, from 2007 to 2013 , also show that 72.3 per cent of South Koreans regard the United States as an 'ally', and only 1.3 per cent think of the United States as a 'hostile country'. On the whole, these objective figures show that a lot of South Koreans still maintain strong pro-American feelings even after the end of the international Cold War confrontations. Myŏngkyu, Park et al. (2014), 2013 T'ong'il ŭisik chosa [Survey on the Opinions on Unification 2013], Institute for Peace and Unification Studies, Seoul, pp. $149^{-1} 5^{1 .}$

${ }^{6}$ Gi-Wook, Shin (1995), Marxism, anti-Americanism, and democracy in South Korea: An examination of nationalist intellectual discourse, Positions, 3(2), pp. $5^{11-}$ 512; Tim, Shorrock (1986), Struggle for democracy in South Korea in the 1980 s and the rise of anti-Americanism, Third World Quarterly, 8(4), pp. 1198-1199.
} 
anti-Americanism in North Korea is a result of 'brainwashing' by the North Korean regime. ${ }^{7}$ In fact, researchers who share similar ideas express their view that anti-Americanism in North Korea is the result of the politics and ideology of the North Korean government more subtly. In other words, according to these researchers, antiAmericanism in North Korea displays top-down dynamics fabricated by politicians, and this kind of explanation can be regarded as a mainstream viewpoint of Korean researchers currently studying North Korea. ${ }^{8}$

Studies that discuss anti-Americanism in North Korea from a historical perspective are also extremely hard to find throughout the world. Bruce Cumings, a critical historian from Chicago University, although not directly discussing anti-Americanism in North Korea, presents the historical background of North Korea's militarism and nuclear policy in detail in his writings about the Korean War and North Korea. Therefore, he indirectly suggests the historical characteristics of anti-Americanism in North Korea. Also, the work of Sŏnghun Han, a Korean sociologist who analyses the relation between the Korean War and anti-Americanism, is noteworthy. However, Han's studies lack the analysis of the North Korean texts during the Korean War, and do not discuss the formation of anti-Americanism among North Koreans from the Japanese colonial period to before the outbreak of the Korean War, which is the key analysis target of this article. ${ }^{9}$

This article insists that Koreans' views of the United States from the early twentieth century to before the outbreak of the Korean War must be examined in order to properly investigate the formation of anti-Americanism in North Korea. North Koreans' generally very

\footnotetext{
${ }^{7}$ Yangsŏp, Sim (2010), Panmirŭl haepuhanda [Dissection of Anti-Americanism], Idam, Seoul, p. 162.

${ }^{8}$ Mikyŏng, Lee (2003), Pukhan ŭi yŏksasŏsul sok ŭi taemiinsik ŭi t'ukching kwa hamŭi [Characteristics and implications of the perception of the United States in the historiography of North Korea], Hankukchŏngch'iwaekyosanonch'ong [Journal of Korean Political and Diplomatic History], 25 (1), pp. 265-299; Sungchoon, Park (2010), AntiAmericanism and structural violence in North Korea, Totǒkyullikwa kyoyuk [Education of the Ethics and Morals], 3o(July), pp. 113-134; Yŏngch’ŏl, Chŏng (201 1), Pukhan ŭi panmi: Ideology, munhwa kuriko kyunyŏl [Anti-Americanism in North Korea: Ideology, culture and the cracks], Sinasea [New Asia], 18(2), pp. 146-170.

${ }^{9}$ Bruce, Cumings (2004), North Korea: Another Country, The New Press, New York; Sŏnghun, Han (2011), Pukhan minchokchuŭi hyŏngsŏng kwa panmi aekukchuŭi kyoyang [Formation of the nationalism and anti-American patriotism in North Korea], Hankukkŭnhyŏntaesa yŏnku [Study of Modern Korean History], 56, pp. 135-172; Sŏnghun, Han (2012), Chŏnchaeng kwa Inmin [War and People], Tolpaekae, Seoul.
} 
positive views of the United States during this period underwent a drastic change during a very short period of time after liberation.

By referring to historical materials dating back to $1945^{-5} 5^{\circ}$, this article shows that the Soviet Union's policy toward the United States in the early years of the Cold War and a change of its view of the world exerted a decisive impact on North Korea's view of the United States in the pre-war phase, and especially in the formation of the 'warmonger' concept. This was quite a new view on the United States in Korea, and such a negative viewpoint was something even the communists in Korea did not exhibit in the wake of liberation from Japanese colonial rule in 1945 . In fact, it was a turnaround of the viewpoint, without any detailed grounds. This article will discuss in detail how the hostile view about the United States, which was merely an artificial stigma on one side before the Korean War, became actualized through the war and how it expanded after the war.

\section{From a cooperator to a warmonger: the making of a Cold War enemy before the Korean War}

\section{A positive view of the United States before and after liberation: a cooperator, a liberator, and a progressive democratic state}

Earlier studies show that the Koreans' perception of the United States during the Japanese colonial period was very positive. ${ }^{10}$ In fact, from the ruling class and intellectuals of the Choson dynasty at the end of the nineteenth century to national liberalists who strived for independence at the end of the Japanese colonial period, Koreans' view of the United States was positive to a great extent. In particular, American missionaries' activities to educate Koreans, arrange for them to study in the United States and stand up for Korea's independence were decisive in contributing to Koreans' positive perception of the United States and anticipation of the United

\footnotetext{
${ }^{10}$ Taewon, Yun (2003), Ilcheshigi ch'inmiwaekyoron kwa taemiinsik [Korean's pro-American diplomacy and perception of America during the Japanese colonial period], Naeil ul yŏnunyŏksa [History for Tomorrow], 12, pp. 32-44; Sangsook, Jeon (2011), Ch’inmi wa panmi ŭi inyŏmkaltŭng: panmi rul t'onghae pon inyŏmkaltong ŭi yŏksachŏk kiwonkwakucho [Ideological conflicts between 'pro-America' and 'antiAmerica': historical origins and structure of Korean ideological conflict seen from 'anti-America'], Tongyangchŏngch'i sasangsa [History of East Asian Political Ideology], $10(1)$, pp. 147-1 71 .
} 
States' support in Korea's fight for independence. Moreover, people such as Sŏ Chaep'il, who personally experienced and was moved by the civilization of the United States, helped publicly strengthen the positive view of the United States:

The United States does not make a habit of starting up wars as other countries do and has established new laws for the comfort of its people and the benefits of the state and ... became the Land of Happiness full of comfort and peacefulness ... When a weak country faces the unfair oppression of a powerful country and is deprived of its right of freedom, the United States helps the weak country by sacrificing its military and wealth. This is the great generosity of the American people. ${ }^{11}$

The positive view of the United States held by some Korean intellectuals at the end of the nineteenth century was further expanded through the desperate situation of being a Japanese colony. Some Koreans were appalled at the United States' support for Japan's annexation in 1910, with 'experts' like Yale's Trumbull Ladd advising Ito Hirobumi, and Teddy Roosevelt's well-known pro-Japanese sympathies. However, the declaration of the selfdetermination of peoples by American President Woodrow Wilson and the Paris Peace Conference based on this declaration, which functioned as a historical background to the March First Independence Movement in 1919, resulted in pro-American tendencies in many Koreans during the Japanese colonial period. Koreans' anticipation of receiving American support in the fight for their independence thus skyrocketed.

However, since the earlier phase of the relationship between Korea and the United States the latter had in fact consistently implemented realistic policies to be faithful to its own interests and those of its powerful neighbouring countries-conduct contrary to the anticipation of the Korean people. When Korea was deprived of its diplomatic rights in 1905 , the United States approved Japan's rule over Korea through the Taft-Katrusa Agreement and it did not even grant an exit permit to Koreans living in the United States who intended to attend the Paris Peace Conference in 1919. As such, Koreans clearly experienced the reality of the dynamics of international relationships. However, the Korean provisional government's activities to petition for independence, centring on the

${ }^{11}$ Tongnip Sinmun [Independence Newspaper], 27 February 1899. 
United States, were continuously implemented until the last moments before liberation. $^{12}$

In addition, it is important to note that the northwestern part of the Korean peninsula centring on Pyongyang, the capital of North Korea, had traditionally been a centre of Christianity in Korea and also the most pro-American region in the Korean peninsula. In the early twentieth century, H. B. Hulbert, a United States missionary to Korea, said the following about the rapid growth of the Christian congregation in the northern regions: 'The northern station of the Presbyterian Mission in Korea attained world-wide notice as being, so far as human estimate can go, the most successful mission station in the world.' ${ }^{13}$ The Christian congregation in Pyŏngan Province and Hwanghae Province in the northwestern part of the peninsula increased exponentially immediately after the Sino-Japanese War in 1894 , and took the lead in the expansion of Christianity in Korea. At the time, 79.3 per cent of Presbyterians in Korea were residents of these areas. ${ }^{14}$

According to a study by Sangt'ae Kim which analysed the characteristics of the leadership of society in the modern Pyŏngan Province, Christianity in Pyŏngan Province was not simply a religion, but was synonymous with the 'civilization of the United States'. The residents of Pyŏngan Province in the latter phase of the Chosŏn dynasty, who yearned for the collapse of the Neo-Confucian order and establishment of a new social system, actively accepted the Christian religion and pursued civilization and enlightenment. That is, to the emerging commercial and industrial classes in Pyŏngan Province who actively accommodated the Christian religion, modernization was synonymous with Americanization and Christianization. The American missionaries were recognized not simply as evangelists, but as the missionaries of 'modernity' and 'American culture'. ${ }^{15}$

${ }^{12}$ Yun, Ilcheshigi ch'inmiwaekyoron kwa taemiinsik [Korean's pro-American diplomacy and perception of America during the Japanese colonial period], pp. 32-36; Jeon, Ch'inmi wa panmi ŭi inyŏmkaltŭng [Ideological conflicts between 'pro-America' and 'anti-America'], pp. 15 o-153.

${ }^{13}$ H. B. Hulbert (1905), The History of Korea, Methodist Publishing House, Seoul, pp. $325-326$.

${ }^{14}$ Institute for Korean Christianity History (1989), Hankukkitokkyo ŭi yoksa I [History of Korean Christianity 1], Kitokkyomunsa, Seoul, p. $25^{8}$.

${ }^{15}$ Sangt'ae, Kim (2002), 'Kŭnhyŏntae P'yŏnganto ch'ulsin sahwaechitoch'ŭng yŏnku [Social leaders of Korean society who hailed from the Pyŏngan-do province in the twentieth century]', PhD thesis, Department of History, Seoul National University, p. 30 . 
According to data from the Japanese government general in Korea in 1932, during the latter phase of the Japanese colonial period, approximately 130,000 out of a total of 280,000 Protestants in Korea were residents of the northwestern regions. ${ }^{16}$ Considering that in 1932 the population percentages of Pyŏngan Province and Hwanghae Province were merely 13.9 per cent and 7.4 per cent, respectively, out of Korea's total population, ${ }^{17}$ the Christian congregation in the northwestern regions was indeed powerful.

In particular, Christianity had a profound impact on the cultivation of emotion and formation of ideology in the northwestern region of the Korean peninsula. For example, the number of schools in Pyŏngan Province and Hwanghae Province was 1,065 , comprising 47.6 per cent of the total number of schools $(2,273)$ in the Korean peninsula. The ratio was much higher than those of Ch'ungch'ong Province (6.6 per cent), Chŏlla Province (6.1 per cent), Kyŏngsang Province (111.7 per cent), and even Seoul and Kyŏnggi Province (14.1 per cent). The reason for this high ratio was the large number of private Christian schools in this region. In $1910,5^{19}$ mission schools (70 per cent of the total) were located in Pyŏngan Province and Hwanghae Province. It was natural that the people who graduated from these schools became important regional leaders, and played a leading role in the creation of the pro-Christian and pro-American atmosphere of this region. Actually, the political character of the National Establishment Preparation Board in Pyŏngan Province, which was dominated by rightwing Christian politicians right after liberation in 1945, clearly shows how important Christian leaders were in this region. ${ }^{18}$

In short, during the period of port opening and the Japanese colonial period, Koreans, as a whole had a positive view of the United States. In addition, the residents of the northwestern regions in the Korean peninsula, who are the key targets of analysis in this study, were the most faithful Christians and pro-American people in all of Korea.

${ }^{16}$ Japanese Government General in Korea (1932), Chosŏn chongkyokŭphyangsa [Korean Religion and Ancestral Rites], Japanese Government General in Korea, Seoul.

${ }^{17}$ Japanese Government General in Korea (1932), Chosŏnch'ongtokpu t'ongkyeyŏnpo [Statistical Year Book of the Japanese Government General in Korea], Japanese Government General in Korea, Seoul.

${ }^{18}$ Kim, 'Kŭnhyŏntae P'yŏnganto ch'ulsin sahwaechitoch'ŭng yŏnku [Social leaders of the Korean society who hailed from the Pyŏngan-do Province in the 2oth century]', pp. 43-45; Chaehun Lee (2005), Haebangchikhu pukhan minjokchuŭi seryŏke taehan soryŏn ŭi insik [Soviet Union's perception of the nationalists in North Korea right after the liberation], Yŏksa bip’yŏng [Critical Review of History], 7o, pp. 284-287. 
Although the Japanese colonial government strongly pushed antiAmerican propaganda in Korea while Japan and the United States were engaged in war for about four years from 12 December 1941 to 15 August 1945 , Koreans, who had suffered deeply from Japanese wartime mobilization, ${ }^{19}$ developed an intensified positive perception of the United States while yearning for the liberation of Korea. Because media activities were officially banned for Koreans during the Pacific War period, it is almost impossible to analyse exactly the influence of Japanese anti-American propaganda or foreigners' perceptions of Koreans. However, all of the Korean newspapers published out of the Korean peninsula publicly and extensively supported the United States, regardless of their political positions. ${ }^{20}$

Koreans' positive view of the United States persisted after Korea's liberation from the Japanese. The United States was recognized as having played a key role in Korea's independence during the Japanese colonial period, and, after Korea's liberation, as 'a liberator' who had saved the Koreans. In addition, the United States was viewed as 'a co-operator' which would assist Korea in pursuing its national task of establishing a new country along with defeating anti-fascism in the days to come. It is necessary to examine this view of the United States because the same view was displayed by communists and even the leadership groups in North Korea in the wake of the liberation.

First, the line of cooperation with the United States established between members of the Korean Communist Party in South Korea is well-known and has been discussed several times in previous studies. Ch'olsun Lee and Namsik Kim criticized the South Korean communists' line of cooperation with the United States, to the extent that it was one of the most important reasons for the decline of the leftist forces in South Korea immediately after liberation. ${ }^{21}$ Jihun Ko concludes that the North Korean Communist Party's policy of

${ }^{19}$ The Japanese colonial government enforced compulsory conscription in August 1943, food controls (through the distribution system) in September 1943, a voluntary student soldier system in January 1944, and even a 'comfort women' system which coerced Korean women into sexual slavery for Japanese soldiers.

${ }^{20}$ Homin, Yang (1994), 'Ilcheshigi taemiinsik [Koreans' perception of the United States during the Japanese colonial period]' in Yŏngik, Yu et al. (eds), Han'guginŭi taemiinshik [Koreans' Perception of the United States], Minŭmsa, Seoul, pp. 220-224; Hojae, Lee (1982), Ich'adaejŏn chung han'guginŭi taeoeinshikkwa chujang [Koreans' foreign perceptions and arguments during the Second World War period], Aseayon'gu [Asia Studies], 25(2), pp. 20-27.

${ }^{21}$ Namsik, Kim (1986), Criticism on the Line of the South Korean Communist Party, Sekye, Seoul; Ch’ŏlsun, Lee (1988), 'Haepangchikhu chwaikseryŏk ŭi taemiinsik [Leftists' 
cooperation with the United States was about the acknowledgment and support of the international order itself, in which the United States played an important role. ${ }^{22}$

In fact, Hŏnyŏng Park, the leader of the Korean Communist Party, described the United States as a 'co-operator' in the anti-fascist line of struggle and that the goal to be fulfilled through the joint struggle was 'progressive democracy'. The Korean Communist Party intended to acknowledge the United States and the Soviet Union as democratic states on the basis that the joint struggle for fascism had not ended, even though the Second World War had, and that the struggle must continue into the future. ${ }^{23}$ The communists in South Korea held fast to this viewpoint until the implementation of Cold War policy by the United States began in earnest against the Soviet Union in 1947. In particular, in memory of American President Franklin Roosevelt, who had decisively promoted the line of cooperation between the United States and the Soviet Union, the communists in South Korea continuously produced official editorials stating that 'President Roosevelt is a great leader of the world's democratic line that secured a foundation for world peace in the postwar period', and that 'Roosevelt's army deserves earnest blessing. ${ }^{24}$

The line of cooperation with the United States employed by the communists in South Korea was also displayed by the communists in North Korea during the same period. On the basis of speeches by Kim Ilsŏng, a North Korean leader, which are found in books like Kim Ilsŏng Chŏchakchip (Collected Writings of Kim Ilsŏng) or Kim Ilsŏng Chŏnchip (Complete Collection of Kim Ilsŏng), some studies claim that Kim Ilsŏng recognized the United States as an 'imperialist

perception of the United States in the wake of liberation from Japanese rule]', MSc thesis, Department of Political Science, Seoul National University.

${ }^{22}$ Jihun, Ko (2007), Haepangchikhu Chosŏnkongsantang ŭi taemiŭisik [Korean Communist Party's view of the United States after the Liberation], Yǒksamuncheyŏnku [Critical Studies on Modern Korean History], 17, p. 210.

${ }^{23}$ Central Committee of the Korean Communist Party, 'Chosonnkongsantang ŭi chuchang [Opinions of the Chosŏn Communist Party]', Haepang Ilbo [Liberation Daily], 6 November 1945; Hŏnyŏng, Pak, 'Haepangchanun kŭtae nofascist ipaksa rŭl p'ongnoham [Liberators reveal secrets of old fascist Dr. Rhee]', Haepang Ilbo, 23 December 1945; Hŏnyŏng, Pak, 'Sekyeminchuchuŭinŭn chŏnchin inminŭl wihan tangtŭli chukwonŭl chwiŏtta [Parties for progressive people take over the sovereignty all over the world]', Haepang Ilbo, 23 April 1946.

${ }^{24}$ South Korean Labor Party, 'Korusi ichuki [The second anniversary of the late Roosevelt]', Taechungsinpo [People's Newspaper], 2o April 1947; South Korean Labor Party, 'Inmin ŭi yŏlhwa wa katŭn yoku wa ungtaehan yŏngnyang ul poicha [Let's show people's enthusiastic requests and great abilities]', Noryŏk Inmin [Laboring People], 8 August 1947. 
country' and officially criticized it immediately after liberation. ${ }^{25}$ However, Kim Ilsŏng's statements about the United States contained in these collections have all been embellished and touched up by later generations of North Koreans. In Kim Ilsŏng's official speeches and the North Korean Communist Party's documents published immediately after liberation, Kim Ilsŏng referred to the United States as a 'liberator'.

Kim Ilsŏng directly criticized the view of the United States employed by specific communist group (the so-called 'Yiyong Group'). This group denied the significance of the struggle by the anti-fascist allied powers and claimed that the war between the Soviet Union and the United States was inevitable. ${ }^{26}$ Chŏngro, the official bulletin of the North Korean Communist Party, also carried a speech by Vyacheslav Molotov, the Soviet Union secretary of foreign affairs, which was an optimistic forecast of international conditions based on cooperation between the Soviet Union and the United States. ${ }^{27}$ Using Molotov's speech as educational material, the Pyŏngyang municipal branch of the Korean Communist Party spread a positive view of the United States by encouraging discussions among all its members. ${ }^{28}$ Kim Ilsŏng continued to emphasize the importance of the United States as a 'liberator' and a 'cooperator': 'The Soviet Union, a socialist country, and the United States, a capitalist country, came in together and liberated North Korea' (October 1945), 'an international relationship as the united front of democratic countries, such as the Soviet Union, the United States and the UK' (1946), and 'I, on behalf of the people of North Korea, would like to thank the people of the Soviet-United States-UK for liberating our country' (August 1947). ${ }^{29}$ In particular,

${ }^{25}$ Chŏng, 'Pukhan ŭi Panmi [Anti-Americanism in North Korea]', pp. 148-150.

26 'Data and evaluation on the North Korean Political Parties and Social Organization, 1945', Central Archive of the Russian Ministry of Defence, Fond 172, Opis 614630 , Delo 5, list 61 (hereafter Central Archive).

${ }^{27}$ Vyacheslav, Molotov, 'Molotov tongchi ŭi kukchechŏngse poko [Reports on the international political situations by Molotov]', Chŏngro, ${ }_{25}$ November 1945.

${ }^{28}$ Pyŏngyang municipal branch of the Korean Communist Party (1945), 'Pyŏngyang sitangpu cheilch'a kongchak ch'ongkyŏlpoko ch'oan [A draft of the final report on the first maneuver of Pyŏngyang branch]', NARA, RG 242.

${ }^{29}$ Kim Ilsŏng, 'Chosŏn kongsantang pukpuchosŏn otoyŏnhaphwae esŏ han tangchochikmunchepoko [Speech of the organisation of the party, spoken in the party congress for five north-western provinces, the Korean Communist Party]', 13 October 1945; Kim Ilsŏng (1946), 'Kimilsŏng changkun sul: Minchoktaetongtankyŏle taehayŏ [General Kim Ilsŏng's speech: about national unification]', Ch'ŏngchin municipal branch of the Chosŏn Communist Party; Kim Ilsŏng, '8.15 haepang ichunyŏn kinyŏmpoko [Commemorative speech on the 2nd anniversary of the Liberation]', Küllocha [Labourer], ${ }_{5}$ August 1947. 
it is noteworthy that Kim used the expression 'liberator' in his public speeches even after the middle of 1947 when implementation of the conflicting Cold War policy of the United States had started in earnest.

However, it must be pointed out that the United States, which was still positively depicted in Kim Ilsŏng's official speeches up until the middle of 1947, had already been referred to as an 'imperialist country' in some of North Korea's official media from the middle of 1946. Important historical incidents leading to such a portrayal included the rupture of the first Joint Soviet-American Commission in May 1946, suppression of Korean communists in South Korea, the appointment of pro-Japanese politicians under the United States military government, and the declaration of a 'Minchukichi nosŏn' (democratic base line) by the North Korean communists. North Korean communists began questioning whether the United States was a 'co-operator' by expressing their anger at the United States military government for actively making use of the Japanese ruling mechanism and human resources, and also at the measures used by the United States to violently suppress communists in South Korea. Immediately after the rupture of the Joint Soviet-American Commission in May 1946, the North Korean Communist Party criticized the United States and used the expression 'imperialist' for the first time. ${ }^{30}$ In addition, from then on both the positive view of the United States as a 'cooperator' in the anti-fascist struggle and the critical view of the United States as an 'imperialist country' coexisted for approximately a year. It was in 1948-49 that an explicit and methodical criticism of the United States began to emerge. Furthermore, the critical view that surfaced around this time was more than simply about the 'imperialist United States'. It further emphasized the new perception of the United States, as will be explained in the next section.

\section{Making the stigma of 'warmonger'}

Recent North Korean propaganda posters targeting the United States mostly depict military images. A poster showing an American soldier at gunpoint carries the phrase 'Death to the Americans'. Another

\footnotetext{
${ }^{30}$ Central Committee of the North Korean Communist Party, 'Somikongtoongwiwonhwae hyuhwaee kwanhan pukchosŏnkongsantang sŏngmyŏngsŏ [The statement on the recess of the Joint Soviet-American Commission]', May 1946.
} 
poster showing a North Korean soldier striking a map of the United States bears the message, 'We do not utter empty words'. There is also a poster that shows the White House being destroyed by a missile, accompanied by the terrifying sentence, 'If an aggressive war is started, we will shatter the Americans first'. An absolute majority of recently produced anti-American propaganda posters depict military or war-related images.

Of course, the most important background to this is the military crisis between North Korea and the United States which has existed since the middle of the 1990s. In addition, the war-related images of the United States formed through the Korean War have also constituted an important historical background. However, it is not widely known that the provocative military images of the United States were formed not during the time of or after the Korean War, but before it. The representative image of the United States propagated before the Korean War, which is discussed in detail later on, was the image of 'warmonger'. What was the historical background and what were the reasons for the United States — which had been recognized as a positive 'co-operator' for abolishing fascism, even by Korean communistsbeing given a provocatively negative image in such a short period of time?

The 'warmonger' image of the United States, which began to appear in official North Korean publications in 1948, was directly influenced by the initiation of the Cold War confrontation and, to be more specific, by the 'two camps' theory and the anti-war peace movements officially propogated by the Soviet Union. In September 1947 the Soviet Union organized the inauguration ceremony of Cominform, a post-war version of Comintern, together with communist leaders of France and Italy as well as six Eastern European countries. During the ceremony, the Soviet Union officially announced the 'two camps' theory to declare 'United States imperialism' as the biggest enemy. The 'two camps' theory, announced by Andrey Zhdanov, chairman of the Soviet Union, was the Soviet Union's official response to the rapid rise of the containment policy of the United States represented by the Truman Doctrine in March 1947 and the Marshall Plan, a European economic aid plan, in June of the same year. The Soviet Union, by organizing Cominform and announcing the 'two camps' theory, interrupted the United States Marshall Plan and opened the door to the so-called 'peace offensive'. From then, Stalin, getting on the bandwagon of fear of war that had spread among the European elites, launched an international peace movement and emphasized the 
discourse of 'peace' as the key to the Soviet Union's cultural strategy until his death. ${ }^{31}$

The main content of the 'two camps' theory is that after the Second World War, the world was divided into an 'imperialistic and anti-democratic camp' led by the United States and an 'antiimperialistic and democratic camp' led by the Soviet Union. According to this theory, the so-called anti-democratic camp was plotting for imperialistic world rule by provoking a 'new war', while the democratic camp, led by the Soviet Union, was upholding 'peace' by fighting against imperialistic world rule. Therefore, the two camps were in conflict and incapable of reaching a compromise. In fact, the international situation schematized by Zhdanov divided the world into a bloc of vice, led by the United States, which intended to provoke a new war, and a bloc of virtue, led by the Soviet Union, to uphold peace. $^{32}$

The 'two camps' theory soon exerted a huge influence all over the world. In particular, to Europeans who had suffered numerous casualties and extensive property damage due to Second World War, the consensus was that peace without war was undeniably a goal of the future. Therefore, the theory of the Soviet Union's upholding of peace in the early years of the Cold War naturally won great support from both the Eastern and Western European countries. In addition the Soviet Union's view of the world, specifically the 'two camps' theory and anti-war and peace stance, began to move into North Korea in an extremely short period of time. As illustrated by a representative slogan of North Korea immediately after liberation, 'Learn from the Soviet Union', North Korea regarded pursuing the national and social structures of the Soviet Union as its highest goal

${ }^{31}$ Uyŏng, Lee (1975), Soryŏn ŭi P'yŏnghwakongchon irone kwanhan yŏnku [A study on the theory of Soviet peaceful coexistence], Pöptaenonch'ong [Journal of Law School], 13, p. 5; Tony, Judt (2005), Postwar: A History of Europe since 1945, Penguin Press, Oxford, pp. $371-372$.

${ }^{32}$ See the following articles for details of the theory of two camps and Soviet peace movements in the early years of the Cold War. Günter, Wernicke (2001), The unity of peace and socialism? The World Peace Council on a Cold War tightrope between the peace struggle and intrasystemic communist conflicts, Peace and Change, 26(3), pp. 332-351; Taewoo, Kim (2012b), Naengchŏn ch'oki sahwaechuŭichinyŏng naepu ŭi chŏnchaengpyŏnghwa tamron ŭi ch'ungtol kwa pukhan ŭi hankunchŏnchaeng insik ŭi pyŏnhwa [Confrontations of understanding war and peace in the socialist camp in the early years of the Cold War, and the changes in the perception of the Korean War in North Korea], Yoksawa hyŏnil [Quarterly Review of Korean History], 83, pp. $375^{-382 .}$ 
of modernization and began strengthening Soviet-related propaganda and agitation activities in extremely diverse ways even down to 'li', the lowest administrative unit. ${ }^{33}$

In fact, North Korean publications and various propaganda and agitation projects during 1948-1950 directly show North Korea's views of the United States based on the 'two camps' theory and the theory of peace. When critical views about the United States began to emerge in North Korea in the latter part of 1947, the United States, which was referred to simply as the 'American imperialist', started to be viewed as a leading country in the Cold War confrontation and a 'war inciter' that would provoke yet another war. A book titled The Foreign Policies of the United States after World War II, published in 1948 by the Propaganda Department of the North Korean Labor Party, describes the international conditions at the time as follows:

Two camps formed in the world after World War II. One was the democratic anti-imperialistic camp led by the Soviet Union and the other was the imperialistic anti-democratic camp led by the United States... There is a large gap between the hope of the imperialists who are intending to provoke a new world war and the real possibility of the outbreak of war. The people of the world do not want a war. In addition, the forces at the front of the peace project all over the world do not fear any threats made by the war inciter and are great enough to completely defeat the invader. ${ }^{34}$

The contents as quoted above are repetitively and frequently shown in other North Korean publications in 1948-1950. Foreign Policy of the United States in the Far East and Pacific Areas, another book published in 1948 by the Propaganda Department of the North Korean Labor Party, concludes with the following sentences: 'The force for peace is strong and great enough to completely destroy the plans of the American invader. And its solidity is demonstrated in struggles to uphold peace. ${ }^{35}$ In addition, a number of books on the international

${ }^{33}$ See the following article to understand how the propaganda campaign about the Soviet political ideology and culture affected North Korean rural areas in 194849. Taewoo, Kim (2006), 1948-49nyŏn pukhan nongch'on ŭi sŏnchŏnsŏntongsaŏp [Propaganda campaigns in the North Korean rural areas, 1948-49], Yoksawa hyŏnsil [Quarterly Review of Korean History], 6o, pp. 127-136.

${ }_{34}$ Propaganda Department of the North Korean Labor Party (1948), Cheichasekyetaechŏnhu ŭi Mikuk üi taewaechŏngch'aek [Foreign Policy of the United States after the Second World War], Labor Party Press, Pyŏngyang, pp. 1-4.

${ }^{35}$ Propaganda Department of the North Korean Labor Party (1948), Küktong mit t'aep'yŏngyangyŏnanchekuke itsŏsoŭi mikuk ŭi chekukchuŭi chŏngch'aek [Foreign policy of the United States in the Far East and Pacific Area], Labor Party Press, Pyŏngyang, p. $5^{8 .}$ 
policies of the United States published in $1949-5^{\circ}$ contain views about the United States such as:

The international conditions as of late are characterised by the formation of an invasion block led by the United States and a powerful movement to uphold peace performed by people all over the world in opposition to the United States imperialists. ${ }^{36}$

The camp upholding peace, which opposes the American imperialists policy to incite a new war, is led by the Soviet Union, the upholder of peace. People's democratic countries, which escaped from imperialistic rule, are standing tall and strong around the Soviet Union. ${ }^{37}$

No matter how much the Americans rave about a new war, their evil plans will certainly be destroyed by the peace-loving people of the world under the leadership of the Soviet Union. ${ }^{38}$

We are outraged because the American imperialistic war inciters are explicitly implementing invasion policies in order to prepare for a new war or to put the arson plans into practice. ${ }^{39}$

As shown in Figure 1 below, illustrations of the time clearly show that the world was divided into the forces of war and the forces of peace, and that the United States was perceived as a war inciter aiming to provoke a new war. The figure on the left shows a hammer engraved with the phrase 'People in love of peace, the global democratic competencies' striking Americans on Wall Street holding a nuclear bomb. In the figure on the right, the national leaders of Taiwan, Japan, the United States, and South Korea are lying squashed under a globe and a gigantic flag of the Soviet Union bearing the phrase 'The main force of the world's anti-war peace camp'. The leaders are holding Marshall Plan documents and a bomb on which 'Inciting a war' is written. These

${ }^{36}$ Propaganda Department of the North Korean Labor Party (1949), Kongkohan pyŏnghwa wa anchŏn ŭl wihan sekyeinmin ŭi t'uchaeng [Struggles of the People of the World to Ensure Stable Peace and Safety], Labor Party Press, Pyŏngyang, p. 1.

${ }^{37}$ Cultural Training Bureau of the National Safety Department (1949), Pyŏnghwa wa minchuchuŭi rŭl wihayŏ chesamch'a sekyetaechŏn ŭi wihyŏp ŭl pantaehanŭn chŏnsekyeminchuchuǔichŏkyŏngnyang ŭi t'uchaeng [Struggles against World War III for the Peace and Democracy of the World by the Democratic Progressive People], Cultural Training Bureau, Pyŏngyang, p. 29.

${ }^{38}$ Sŏngnim Kim, 'Kukchepanchŏnil ŭl machŭmyŏ [Greeting the day of international anti-war]', Hand-written note for a lecture to the North Korean Army, 2 August 1949 .

${ }^{39}$ Kukchemuncheyŏnkyhwae [Research Association of International Problems] (1950), Patshohwahanŭn mikuk [Fascistising America], Culture Press, Pyŏngyang, p. 1. 

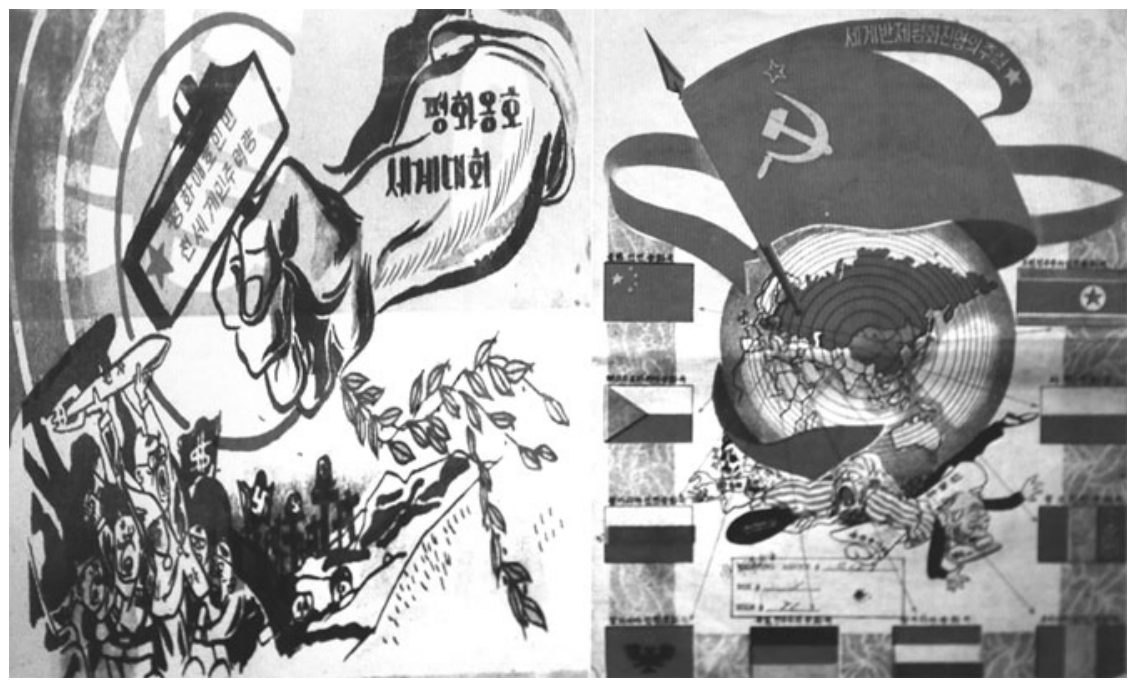

Figure 1. North Korean propaganda illustrations showing their view of the world. Source: Hwalsal [An arrow], 9, Cartoon and Magazine Company, Pyŏngyang, June 1 949, p. 2 (left); Hwalsal [An arrow], 15, Cartoon and Magazine Company, Pyŏngyang, February 1950, p. 16 (right).

figures vividly illustrate the situation in North Korea at the time when its thinking about the world was set within a Soviet Union-Cold War framework.

From $194^{8}$ to $195^{\circ}$, the North Korean government also actively took part in the peace movements that were implemented under the Soviet Union's logic of the 'two camps' theory. An example is the North Korean government's participation in the World Congress of Partisans of Peace, held in Paris and Prague in April 1949, and the Stockholm Appeal signature collecting campaign, held in March 1950. The World Congress of Partisans of Peace was attended by 1,784 representatives of 72 countries and the Stockholm Appeal was signed by 273,470,566 people by July $195^{\circ}$ (which was equivalent to approximately oneeighth of the world's population and a quarter of the adult population at the time). These figures are evidence of the great influence exerted throughout the world by the anti-war peace movements centring on the disarmament of nuclear weapons after Second World War. And North Korea had no choice but to take part in these peace movements led by the Soviet Union. ${ }^{40}$

${ }^{40}$ United States House of Representative (1951), Report on the Communist 'Peace' Offensive, United States Government Printing Office, Washington DC, pp. 16, 34; 
North Korea sent a delegation of Ch'angchun Kim, Sŏlya Han, and Chŏngae Pak to the World Congress of Partisans of Peace. Sorlya Han spoke of the significance of the event: 'For the peace and safety of mankind, we see today that a solemn struggle of the peace-loving people of the world who oppose the new war inciters is spreading throughout the globe. Under the circumstances, this congress holds the greatest significance for the future and culture of mankind'. ${ }^{41}$ The Stockholm Appeal signature collecting campaign, which was extensively carried out all over North Korea immediately before the outbreak of the Korean War in 1950, was the climax of the peace movement in North Korea. Rodong Sinmun [Labor Newspaper], an official bulletin of the North Korean Labor Party, extensively publicised the signature collecting campaign on a daily basis from 21 April to 28 May $195^{\circ}$. The newspaper officially announced that 5,680 ,ooo people had participated in the signature collecting campaign. Stories about participating in the signature collecting campaign in various regions were covered by Rodong Sinmun one after another and, without fail, the 'Americans' conspiracy to provoke a war' was raised as a subject of criticism. ${ }^{42}$

However, from the standpoint of ordinary people in North Korea, the image of the United States as a 'war inciter' was in fact the result of topdown coercion. It was a concept foisted by the Soviet Union onto North Korea, and by the North Korean leadership onto the people of North Korea. According to previous studies, North Korean leaders, including Kim Ilsŏng, openly began to express their hostility towards the United States around 1948 when the prospect of the division of the Korean peninsula became a reality. ${ }^{43}$ They began to call the United States the

Wernicke, The unity of peace and socialism?, p. 334; Kim, Naengchŏn ch'oki sahwaechuŭichinyŏng naepu ŭi chŏnchaengpyŏnghwa tamron ŭi ch'ungtol kwa pukhan ŭi hankunchŏnchaeng insik ŭi pyŏnhwa [Confrontations of Understanding War and Peace in the Socialist Camp in the Early Years of the Cold War, and the Changes in the Perception of the Korean War in North Korea], pp. 378-379.

${ }^{41}$ National Committee of the Partisans of Peace (1949), 'Han Sŏlyasi ŭi poko [Statement of Sŏlya Han]' in Pyŏnghwaongho sekyetaehwae munhŏnchip [Documents of World Congress of Partisans of Peace], National People Press, Pyongyang, p. 1.

42 'Pyŏnghwaonghosŏmyŏnguntong ŭn chŏninminchŏk untongŭro twaekoitta [The signature-seeking campaign for the partisans of peace is becoming a national movement]', Rodong Sinmun [Labor Newspaper], 21 April 1950; 'Pyŏnghwaonghosŏmyŏnguntong ch'amkacha opaekyuksipp'almyŏng [The number of participants in the signature-seeking campaign for the partisans of peace reached 5,680,ooo]', Rodong Sinmun [Labor Newspaper], 28 May $195^{\circ}$.

${ }^{43}$ Homin Yang (2008), Chosŏn rodongdang ŭi michekukchuŭiron [American imperialism of the Korean Labor Party], Pukhanhakpo [Bulletin of the Studies of North 
'American imperialists' when expressing their antagonism towards United States policy on the Korean peninsula. For example, Tubong Kim, chairman of the Supreme People's Assembly of North Korea, denounced South Korean politicians in the joint meeting between North and South Korean leaders in 1948. He claimed that the 'so-called "leaders" of South Korea ... could not give any insight into the nature of the American imperialist'. ${ }^{44}$ In short, Soviet antagonism towards the United States around 1948 coincided with the anti-Americanism of North Korean leaders, which made the top-down process easier.

However, as mentioned earlier, the general image of the United States remained positive in Korea for a long time. During $1945^{-47}$, even South Korean and North Korean communists referred to the United States as a 'liberator' or a 'cooperator'. Therefore, the concept of the 'American imperialist warmonger' promoted in 1948-49 was, in fact, the result of a drastic turnaround due to top-down dynamics. The image of the United States changed from one extreme to another in a short period of time. Accordingly, it is important to investigate the level of authenticity with which the North Korean people accepted the image of the United States as a warmonger. The negative image of the United States which spread throughout North Korea from 1948 to 1949 was merely a perplexing stigma which lacked substantiated grounds.

However, North Koreans today do not feel any qualms about associating the United States with the image of war. This is in fact a natural association for them. At the heart of this negative and powerful anti-Americanism in North Korea are the experiences of the Korean War that actualized the image of the United States as a 'warmonger', and which had been merely a top-down process in $1948-49$.

\section{Actualized stigma, expanded anti-Americanism}

Formation of real hostility during the war

The war shook up the daily lives of all North Koreans. During the three-year war, the biggest goal of most North Koreans was survival.

Korea], 32, p. 141; Chŏng, Pukhan ŭi panmi [Anti-Americanism in North Korea], p. 149 .

${ }^{44}$ National History Compilation Committee (1994), Pukhan kwankye saryochip I [Source Book of the North Korea 1], NHCG, Seoul, pp. 457-458. 
From the moment the war was started by the North Korean Army on 25June 1950, North Korean residents in the rear areas had to endure fear of death, and an absolute lack of basic necessities throughout the three years of its duration. For around two years, after a frontline became fixed near the current border between South and North Korea in the summer of $195^{1}$, people residing in the rear areas in South Korea experienced relatively peaceful days. However, North Korean residents had to face the deaths of their families and neighbours due to massive bombings by the United States Air Force which continued throughout the war. Of course, most parts of North Korea's territory, including cities and villages, were left in ruins during this period.

It is not possible that the leadership of the Soviet Union, China, and North Korea were unaware of the great power of the United States armed forces prior to the Korean War. Only five years before the Korean War broke out, major Japanese cities next to the Korean peninsula were reduced to ashes as a result of atomic and incendiary bombing by the United States armed forces. In addition, the Soviet Union did not have sufficient power to fight in a war against the United States in $195^{\circ}$. The Soviet Union, which suffered the most extensive property damage and greatest number of casualties during the Second World War, had still not recovered from the war's devastating effects. In March 1949, when Kim Ilsŏng requested approval for an invasion of South Korea from Stalin for the first time, Stalin refused resolutely. The major reason for this objection to the war was the presence of the United States armed forces in the Korean peninsula. Stalin said that 'the United States armed forces still stay in South Korea. If hostilities erupt, the United States armed forces will make military intervention in Korea.' Stalin wanted to avoid a total war, with the possibility of intervention by the United States, in whatever way possible. ${ }^{45}$

Eventually, however, in $195^{\circ}$ Stalin gave in to Kim Ilsŏng's desire for a war. The reasons for this decision were also associated with the United States: Stalin rated highly the Chinese communists' victory during the Chinese Civil War in October 1949 and focused on the fact that the United States armed forces had not directly intervened during the course of the war. In 1949, the Soviet Union succeeded in developing nuclear weapons, which until then had been exclusively a

\footnotetext{
${ }^{45}$ International Department of the Communist Party of the Soviet Union, 'Memorandum of conversation between Stalin and Kim Ilsŏng', Central Archive, 7 March 1949; Anatory Torkunov (2003), Hankukchŏnchaeng üi chinsil kwa susukeki [The War in Korea 1950-1953], Editor, Seoul, p. 44.
} 
weapon of the United States. As a result, the Soviet Union was able to act as a deterrent force against the United States to a certain extent. Stalin was therefore inclined to assent to the continuous demands for a war by Kim Ilsŏng, who was actively going along with the rapid changes in East Asia during 1949-50. In this way, continuously considering the possibility of the United States' entry into the war, communist leaders started the Korean War on the morning of 25 June $195^{\text {o. }}{ }^{46}$

However, as soon as the war started, the United States very quickly and aggressively intervened. Stalin and Kim Ilsŏng exchanged messages of concern through Terenti Stykov, the Soviet ambassador to North Korea, and expressed their anxieties. On 1 July 1950, immediately after the first bombing in North Korea by the United States Air Force, Stalin said, 'Report the reaction of the North Korean leadership about the raid by the United States Air Force. I want to know if they fell into a panic or strongly went through it. ${ }^{47}$ On the same day, Stykov, in a telegram to Stalin, responded:

Kim Ilsŏng and Park Hŏn-yŏng are aware that North Korea is facing difficulties due to the United States Air Force's air raid in the Democratic People's Republic of Korea ... Some leaders, such as Kim Tupong and Hong Myŏnghi, expressed opinions that it would be difficult for North Korea to continuously lead the war by fighting against the United States armed forces and cautiously asked Kim Ilsong about the Soviet Union's stance about this issue. $^{48}$

One week later, Stykov gave further information about the situation Kim Ilsŏng faced: 'Kim Ilsŏng says that everyone is phoning him to report the bombings and gigantic destructions by the United States Air Force ... When I met him, I saw for the first time that Kim Ilsŏng was extremely angry and was panicky. 49

${ }^{46}$ International Department of the Communist Party of the Soviet Union, 'Kim Ilsŏng's visit to Soviet Union (3o March-25 April 1950)', Central Archive, April 1950; Evgeny Bazanov and Natalia Bazanova (1998), Soryŏn charyo ro pon Hankukchŏnchaeng $\breve{u} i$ chŏnmal [The Most Mysterious War of Twentieth-Century: Korean Conflict $195^{\circ}-$ 1953 based on Soviet Archives], Yŏlim, Seoul, pp. 52-55.

${ }_{47}$ Stalin, 'Telegram to Stykov', Central Archive, 1 July 1950; National Institute of Korean History (NIKH) (2006), Hankukchŏnchaeng, munsŏ wa charyo, 1950-53 [The Korean War, Documents and Materials, 1950-53], NIKH, Seoul, p. 67.

${ }^{48}$ Stykov, 'Telegram to Stalin', Central Archive, 1 July 1950; National Institute of Korean History, Hankukchŏnchaeng, munsŏ wa charyo, 1950-53 [The Korean War, Documents and Materials, 1950-53], p. 69.

${ }^{49}$ Stykov, 'Telegram to Stalin', Central Archive, 8 July 1950; National Institute of Korean History, Hankukchŏnchaeng, munsŏ wa charyo, 1950-53 [The Korean War, Documents and Materials, 1950-53], pp. 77-78. 
Stalin's apprehension and Kim Ilsŏng's anxiety about the United States' entry into the war became a fearful reality through military operations conducted by the United States armed forces. Most military histories assess the first three months of the Korean War as a time of overwhelming victory by the North Korean army. In fact, during this period, the North Korean army occupied more than go per cent of the territory of the Korean peninsula. Therefore, the assessment cannot be regarded as incorrect. However, during the same period, an entirely different situation was unfolding in large cities all over North Korea. In North Korea's major cities of P'yŏngyang, Ch'ŏngchin, Hamhŭng, Hŭngnam, Chinnamp'o, and Wonsan, the air strikes of the United States Air Force destroyed almost all of the key military facilities, communication centres, and industrial facilities. During the course of these air strikes, a significant number of civilians were also killed. ${ }^{50}$

However, aerial bombings during the first three months of the war were carried out with some restrictions and moderation. This is because the United States Air Force clearly adhered to a precision bombing policy, and tried to implement it to some degree in strategic bombings in the first phase of the war. The B-29 medium bombers aimed to destroy specific targets that were designated at briefings before sorties. Moreover, for the first three months of the Korean War, incendiary bombs, which had been used to burn down major cities in Germany and Japan during the Second World War, were not used. This was an attempt to accommodate public opinions formed after the Second World War both in and outside of the United States, which emphasized the necessity of protecting civilians during a war. Because of this military policy, overwhelming destruction, as had occurred during the Second World War, was avoided, at least during the early months of the Korean War. ${ }^{51}$

The situation was the same in Pyŏngyang, the capital of North Korea. Pyŏngyang was clearly saved from overwhelming destruction in the initial phase of the war. Furthermore, there were many proAmerican Christians who extensively welcomed the United States armed forces in Pyŏngyang. Howard Moffett, son of the United States Presbyterian missionary Samuel Moffett, entered Pyŏngyang under occupation by the UN forces as a medical doctor for the Fifth Air

\footnotetext{
${ }^{50}$ Taewoo, Kim (2012a), Limited war, unlimited targets: United States Air Force bombing of North Korea during the Korean War, Critical Asian Studies, 43(2), pp. 474-479.

${ }^{51}$ Kim, Limited war, unlimited targets, pp. 469-474.
} 
Force in October 1950. He recorded, 'I asked one of the people I first met in Pyŏngyang if he was a Christian. He said he was and asked me if I knew "Reverend Ma". Reverend Ma is my father's Korean name. Realising this, he held my hands as if I was his long-lost brother and started telling this to all people on the street. ${ }^{52}$ The United States army chaplain, Harold Voelkel, also described the situation in Pyŏngyang as follows:

There was a notice of a joint service at Sormun Church at 2 in the afternoon ... At 2:10, the large church was packed with people. Those outside the church could not get in ... The atmosphere there was that of liberation, which pulled these people in like a magnet after the tension of the Japanese colonial period and suppression by communists. ${ }^{53}$

The descriptions of Korean Christians welcoming Americans with joy given above could have been slightly exaggerated. However, such descriptions do not seem altogether groundless considering that it had been only two years since the establishment of the government of North Korea and therefore that the negative image of the United States had only been around two years. In fact, the image of the United States as a 'warmonger', which spread rapidly during 1948-49, did not touch the hearts of the North Korean people. Furthermore, up to this point, the scene in Pyŏngyang was a far cry from the description given at the time of the close of war which claimed complete destruction of the city. However, the joy of some Christians did not last long, because from November $195^{\circ}$ the United States armed forces started implementing a full-on demolition operation as they had during the Second World War.

On 5 November $195^{\circ}$, the scorched earth policy of Douglas MacArthur, commander-in-chief of the UN forces, made all cities and villages in North Korea targets of destruction by terminating the existing precision bombing policy. This was a ruthless military policy established when UN forces were facing an enormous crisis caused by the appearance of a new enemy, the Chinese People's Volunteer Army. Until the end of the Korean War, civilian areas in North Korea had to continuously withstand the ruthless bombings of the United

\footnotetext{
${ }^{52}$ Howard Moffett, 'Letter to John Smith, Korea secretary, Presbyterian Board of Foreign Missions', 25 October $195^{\circ}$.

${ }^{53}$ Harold Voelkel, 'Letter to Presbyterian Board of Foreign Missions, New York', 29 October $195^{\circ}$.
} 
States Air Force. By the time the war ended, most of the villages and cities in North Korea had been reduced to ruins. ${ }^{54}$

According to various reports on the damage caused by the war, published by the North Korean government during the war, the damages suffered by civilians differed somewhat at different stages of the war's development. During the initial phase of the war (JuneSeptember 1950) while the North Korean army occupied South Korea, most war damages were caused by air strikes. From October $195^{\circ}$ to June $195^{1}$, when UN forces occupied and retreated from North Korea, respectively, war damages consisted of those caused by extensive air strikes due to implementation of the scorched earth policy and also of massacres by UN forces and the sexual assault of Korean women by members of the United States armed forces. During the remaining period, the reports mainly concerned the issues of air strikes and germ warfare by the United States. ${ }^{55}$

Various reports, international statements, and newspaper articles in North Korea described the atrocities committed by the United States very realistically. Some are suspicious of the authenticity of the articles because they contained excessive descriptions of the atrocities. In these articles, the expressions 'American imperialism' and 'warmonger' were no longer used to describe the United States. Rather, the United States was described as a 'vampire', 'mugger', 'beast', and 'mortal enemy'.

The examples include the serials run in Rodong Sinmun [Labour Newspaper] such as 'we will certainly have our revenge on the American muggers and the Syngman Rhee traitors' and 'The brutality of the evil enemies'. These serials realistically described civilian damages suffered as a result of the brutal massacres, ruthless bombings, sexual assaults, and arson committed by UN forces together with various testimonies. For around one week in 1951, Rodong Sinmun published articles describing shocking acts of brutality day after day, such as the incident of American 'vampires' taking off the pants of an abducted Korean Workers' Party member and practising shooting by

\footnotetext{
${ }^{54}$ Kim, Limited war, unlimited targets, pp. 479-489.

${ }^{55}$ Representative reports on the damages of the war published by the North Korean government are as follows. DPRK National Unification and Democracy Front, 'Mikuk muryŏk kansŏpchadul kwa leesŭngman topaedulŭi manhenge tehan chokukt'ongil minjujuŭi Ch'ŏnsŏn chosawiwonhoe podo che 1-4 ho [Report Nos. 1-4, Atrocities of the United States and South Korean government, investigated by National Unification and Democracy Front]', No. 1, 18 August 1950; No. 2, 18 September 1950; No. 3, 26 December 1950; No. 4, 1 March 1951; No. 5, 19 February 1953.
} 
firing 3 oo bullets at his genitals. ${ }^{56}$ They also described the American 'mortal enemy' burning around 200 refugees using gasoline, ${ }^{57}$ seven or eight American 'killers' raping a woman and killing her by setting her on fire, ${ }^{58}$ and the raving American muggers and Syngman Rhee traitors abducting the three-year-old daughter of the chairman of the party, whom he was carrying on his back, and burying the baby in snow. ${ }^{59}$ In addition, it is noteworthy that the newspaper articles described the UN forces as 'employed soldiers of the American killers' without specifying their nationalities other than that they were from the United States. What is more, even the rightist local residents and South Korean soldiers were often described as 'employed soldiers of America'. During the course of the Korean War, the United States was depicted as the biggest enemy of North Korea and an evil demon.

After the middle of $195^{2}$, criticism aimed at the United States mostly focused on germ warfare. In particular, Rodong Sinmun intended to add to the righteousness of the North Korean government's assertion that germ warfare had taken place by publishing interviews with, and the long confessions of, John Quinn and Kenneth Enoch, American prisoners of war, in May 1952. They specifically confessed that they actually had carried out germ warfare. ${ }^{60}$ Moreover, Rodong Sinmun published an article together with related photos, about the existence of spies who had been captured while secretly investigating the effects of germ warfare. ${ }^{61}$

Of course, it still remains to be discussed in academic circles whether the United States armed forces actually did carry out germ warfare. ${ }^{62}$ What needs to be noted particuarly in this article is

${ }^{56}$ Rodong Sinmun [Labor Newspaper], 31 March $195^{1 .}$

${ }^{57}$ Ibid., 4 April 1951.

${ }^{58}$ Ibid., 5 April 1951 .

${ }^{59}$ Ibid., 7 April 1951 .

${ }^{60}$ Ibid., 5, 6 May $195^{2 .}$

${ }^{61}$ Ibid., 7, 9 May 1952.

${ }^{62}$ Much controversy still surrounds accusations that during the Korean War American forces used biological warfare against North Korea and China. For example, Conrad Crane, research professor of the United States Army War College, insists that, although the United States attempted to accelerate its development and acquisition of such weapons during that period, its efforts to create viable biological warfare capability were unsuccessful. However, Endicott and Hagerman, historians of York University in Toronto, claim that there is a long circumstantial trail of corroborative evidence that the United States experimented with biological weapons in Korea. According to them, the United States biological warfare programme during the Second World War quickly grew to be one of the largest wartime scientific projects in American history, second only to the Manhattan Project, which had created the atomic 
the continued running of such articles and the fear of diseases as well as hatred for the United States that must have spread rapidly among the people of North Korea. The North Korean government did not stop at widely circulating articles about germ warfare-it implemented a strict epidemics control project to cover even the lowest administrative districts throughout the country. ${ }^{63}$ The vaccination and epidemic control projects, which were carried out thoroughly, must have amplified the North Koreans' fear and loathing of the United States, regardless of the actual execution of germ warfare.

During the war, activities aimed at publicizing the brutality of the United States were carried out in North Korea through exhibitions and street broadcasting. For example, in March 1951, the Cultural Association of Korean-Soviet Union in Pyongyang held the 'Exhibition of the brutal acts the United States committed in North Korea' to vividly expose the actions of the United States armed forces during the war period through photographs, posters, and paintings. The photos of this exhibition carried in Rodong Sinmun openly showed shocking scenes of civilian massacres in North Korea. According to one article, the exhibition was attended not only by North Korean and Chinese soldiers, but also a large number of 'labourers, farmers, office workers, students and women'.64

A photograph featured in Rodong Sinmun on 28 May $195^{2}$ is also noteworthy in relation to anti-America propaganda during the war. The photograph shows the scene of a live broadcast of the trial for the Sinch'on Massacre, a representative massacre that resulted in the slaughter of about 3o,ooo North Korean civilians. Many citizens of Pyŏngyang gathered on the streets to hear the result of the trial. As testimonies of witnesses, spread through loudspeakers, claiming that they had suffered damages from the United States armed forces' massacre of civilians, the citizens expressed strong hatred and wrath toward the United States. Listening to the broadcast, one citizen

bomb. Furthermore, the United States Department of Defense boosted funding for biological warfare development: $\$ 345^{2}$ million for $195^{1-1} 953$, which was a significant increase from $\$ 5.3$ million for fiscal year $195^{\circ}$. See Conrad, Crane (2002), No practical capabilities: American biological and chemical warfare programs during the Korean War, Perspectives in Biology and Medicine, 45(2), pp. 241-249; Stephen Endicott and Edward Hagerman (1998), The United States and Biological Warfare, Indiana University Press, Indiana.

${ }^{63}$ DPRK Military Committee, 'Resolution No. 65: Measures against enemy's germ weapon', 20 February 1952; DPRK Military Committee, 'Resolution No. 275: Strengthening national quarantine inspection', 6 June $195^{2}$.

${ }^{64}$ Rodong Sinmun [Labor Newspaper], 26 March $195^{1 .}$ 
became outraged and said, 'There is no one more evil than the Americans.' Another infuriated woman said, 'I became clearly aware of the inhumane beastliness of the Americans. ${ }^{65}$

According to a previous study, the Sino-Japanese War (1894) played the most important role in rapidly spreading the Christian religion in North Korea. During the Sino-Japanese War, the northwestern part of the Korean peninsula became the main battlefield between the two countries. The Christians, who became more dependent on their religion under the extreme conditions of the Sino-Japanese War, spread the gospel to nearby shelters and the people gathered in churches led by Western missionaries in order to have their lives and properties protected. As a result, Christianity began spreading to all corners in Pyongan Province and the northern part of Hwanghae Province. ${ }^{66}$ During the Open Port period, the situation rapidly amplified the North Koreans' positive view of the United States and the Christian religion. On the contrary, the Korean War led to a completely opposite situation. To North Koreans, the United States was no longer a protector of the people. It was instead a destroyer and a slaughterer. The dishonourable stigma of warmonger attributed to the United States during an extremely short period of time before the war was now engraved in the hearts of North Koreans as an undeniable truth.

\section{The systemization and routinization of anti-Americanism}

After the Korean War, the United States was degraded to a subhuman level in North Korea. The United States was no more than a 'wild dog', in reference to the title of a novel by Sŏlya Han published during the Korean War. Also, the United States was portrayed as an invader whose only goal had been to pillage Korea from the initial phase of contact with the Koreans. The historical background of the novel Wild Dogs was the Japanese colonial period. However, the United States was depicted as a vampire that sucked the blood out of Korean people during this time. ${ }^{67}$

${ }^{65}$ Rodong Sinmun [Labor Newspaper], 28 March 1951.

${ }^{66}$ Manyŏl, Lee (1978), 'Hanmal kitokkyoin ŭi minchokŭisik hyŏngsŏngkwachŏng [Formation of national consciousness of the Christians in the end of Chosonn dynasty]' in Hankukkitokkyo wa minchokuntong [Korean Christianity and National Movements], Posŏng, Seoul, 1978, pp. 16-21.

${ }^{67}$ Sŏlya, Han (1951), Süngnyangi [Wild Dogs], Cultural Front Press, Pyŏngyang. 
However, the depiction of the United States in Sŏlya Han's novel was not simply a coincidental or a personal creation. It was in fact a result of the North Korean government's direct intervention in the content and style of literary works. On 24 December 1950, Kim Ilsŏng met with authors, artists, and scientists in the midst of the crisis of losing the war. He instructed them that 'our art must contribute to accelerate our victory in the war'. Kim Ilsŏng made the direct demand, 'Create many revolutionary works that reveal and punish the unforgivable crimes and brutality the American imperialists have committed on this land. ${ }^{68}$ In fact, following this meeting, various types of novels, films, and paintings expressing extreme anti-Americanism began to be published and distributed to the people.

It is important to note that anti-Americanism in North Korea after the war was deeply embedded in public educational curriculums for young students. For example, a mathematics textbook for second grade students in Inmin Hakkyo, a primary school, published in 1986 teaches the concepts of addition and subtraction using the following questions 'During the national liberation war [the Korean War], the North Korean soldiers killed 278 American imperialist wild dogs and puppet army soldiers during a battle. 196 were American imperialist wild dogs and the rest were puppet army soldiers. How many of the puppet army soldiers were killed? ${ }^{69}$ Insulting and aggressive terms like 'wild dog', 'killing', and 'bastard' are frequently used in all primary school textbooks for the subjects of Korean, mathematics, ethics, and music, among others. It was found that one primary school textbook used the terms 'bastard', 'American bastard', and 'enemy bastard' 287, 139, and 85 times, respectively. ${ }^{70}$ Anti-Americanism in North Korea, which was present in every subject in primary school, targeted even young children systematically and routinely.

From a historical point of view, anti-Americanism expanded more systematically in North Korea during the late 1950s. Kim Ilsŏng officially presented the notion of 'Juche (self-reliance)' in his address on 28 December 1955, for the first time in North Korean history.

${ }^{68}$ Sahwaekwahakwon [Social Science Research Institute] (1978), Chosŏnmunhaksa, 1945-1958 [History of Korean Literature, 1945-1958], Science and Encyclopedia Press, Pyŏngyang, p. 144.

${ }^{69}$ Hwaeil, Kim (1986), Suhak: Inminhakkyo 3 [Mathmatics: Elementary school 3], Educational Book Press, Pyŏngyang, p. 29.

${ }^{70}$ Pukhanyonkuso [Institute for North Korean Studies] (ed.) (1983), Pukhanch'ongkam [Comprehensive survey of North Korea], Institute for North Korean Studies, Seoul, p. 1301. 
He stressed the importance of North Korea's independence from foreign powers in this official address. ${ }^{71}$ Although the emphasis on self-reliance in this period was meant to counter the serious diplomatic pressure placed on North Korea by China and the Soviet Union, antagonism towards the United States also began to spread systematically during this period. A study by Sŏnghun Han shows the important role played by anti-foreign sentiment throughout North Korean society, both internally and externally, during the crisis in North Korea in 1957-58. ${ }^{72}$ In fact, North Korean newspapers at that time portrayed a distinctly different social atmosphere than previously. For example, a rally commemorating the Korean War on 25 June $195^{8}$ was carried out in quite a different format and its content differed from that of the previous assemblies. From 1953 to 1957, the North Korean government held relatively brief assemblies about the Korean War, inviting only key personnel of the North Korean leadership and diplomatic representatives residing in North Korea. ${ }^{73}$ However, on 25 June $195^{8}$, hundreds of thousands of people, including 300,000 at Kim Ilsŏng Square in Pyŏngyang, attended popular rallies about the Korean War in key cities all over North Korea. The 300,00o people who gathered in Pyŏngyang, marched on, carrying portraits of Kim Ilsŏng and the national flag of North Korea, and demanded the immediate withdrawal of the United States armed forces. ${ }^{74}$

The popular assembly on 25 June was firmly established as one of North Korea's main annual events after 1959. From $195^{6}$ to $195^{8}$, North Korea recognized 25 June each year as the 'day of struggle against the Americans'. In 1959, it began to be called the 'day of struggle for withdrawal of the United States armed forces from South Korea'. ${ }^{75}$ Moreover, in 1959, North Korea set the period from 25 June, the day of the outbreak of the Korean War, to 27 July, the day on which the ceasefire agreement was signed, as a 'month of joint anti-American struggle' and organized anti-American rallies in

\footnotetext{
${ }^{71}$ Kim Ilsŏng (1968), 'Sasang saŏp esŏ kyojojuŭi wa hyŏngshikchuŭi rŭl toech'ihago juche rŭl hwakriphalte taehayŏ [About establishing self-reliance while eradicating dogmatism and formalism in propagandist work]' in Kim Ilsŏng chŏjak sŏnjip 4 [Kim Ilsŏng Anthology 4], Korean Labor Party, Pyŏngyang.

${ }^{72}$ Han, Pukhan minchokchuŭi hyŏngsŏng kwa panmi aekukchuŭi kyoyang [Formation of the Nationalism and anti-American Patriotism in North Korea], pp. $14^{6-1} 5^{8 .}$

${ }^{73}$ Rodong Sinmun [Labor Newspaper], 25 June 1955; 25 June 1956; 25 June 1957.

${ }^{74}$ Ibid., 26 June 1958.

${ }^{75}$ Ibid., 25 June 1959 .
} 
various formats. The month of joint anti-American struggle continued every year until 2000, which is when the atmosphere of peace reached its climax in the Korean peninsula as a result of the inter-Korean summit. ${ }^{76}$

The central reasons for the rapid spread of anti-Americanism in North Korea in the latter part of the $195^{\circ}$ os are closely related to changes in American military policy regarding the Korean peninsula. The United States, violating a provision to ban the introduction of new weapons from the outside-one of the key points of the military armistice-started deploying around ten types of nuclear weapons, Honest John missiles, and Phantom fighters in South Korea from January 1958. North Korea's reaction to these military measures was instantaneous and offensive. Kim Ilsŏng directly criticized the attempts of the United States to establish South Korea as its nuclear base, and North Korea's Supreme People's Assembly held a largescale mass rally in opposition to the deployment of nuclear weapons in South Korea by declaring the establishment of the Korean peninsula as a nuclear-free zone. ${ }^{77}$ Only five years after the end of the war, the newly emerging military crisis in the Korean peninsula was extremely threatening to the North Korean regime and its people.

It seems that the crisis of North Korea resulting from the tactical nuclear weapons allocation of the United States in the latter part of the $195^{\mathrm{O}}$, together with the systematic spread of the anti-American movement, served as a direct momentum for the establishment of an anti-American shrine called 'Sinch'ŏn Museum' in North Korea. As discussed previously, North Korea claimed that more than 30,000 of its people were massacred by American armed forces in Sinch'ŏn during the Korean War. In 1958, the North Korean government built a large museum at a location representative of American brutality and used it as a space of learning about the events of the Korean War. North Korea claims that, since the museum's opening on 25 June 1960, about 3,000-4,00o people visit Sinch'ŏn Museum each day. During the 'month of joint anti-American struggle', the museum is visited by around 10 ,ooo people daily. A South Korean scholar who visited the museum wrote that North Korean visitors would naturally

\footnotetext{
${ }^{76}$ Sanghwan, Kim (1993), 6.25 Chŏnchaeng ul yiyonghan pukhan ŭi chuminkyoyang silt'ae [North Korea's education of its people using subjects of the Korean War], Pukhan [North Korea], 258, pp. 44-45.

${ }^{77}$ Han, Pukhan minchokchuŭi hyŏngsŏng kwa panmi aekukchuŭi kyoyang [Formation of the nationalism and anti-American patriotism in North Korea], pp. $153^{-1} 55^{\text {. }}$
} 
take home with them a sentiment of 'basic fury' about the United States regardless of the authenticity of the exhibits in the museum. ${ }^{78}$

Chinung Kang, a sociologist at Minnesota University who conducted in-depth interviews with a total of 62 North Korean defectors from 2006 to 2009 , had very interesting research results in relation to the historical characteristics of anti-Americanism in North Korea. A 24year-old woman talked about her memory of Sinch'on Museum: 'I was enraged at the miserable deaths of our ancestors and vowed that I would fight with arms against the Americans.' A 70-year-old female defector who lost her parents at the age of 11 due to bombing by the United States Air Force during the Korean War and grew up in an orphanage said, 'I thought of my parents who had passed away when I was young every time I saw airplanes in Korea. I have felt extreme hatred for the Americans since I was young. Anti-Americanism was learned at school. But, it grew even further based on my personal experiences. ${ }^{79}$

Chinmok Park, who lived in Pyŏngyang during the war, spoke about his experiences as follows: 'I had to go in and out of my house numerous times in a day whenever aerial bombing proceeded. It was a living hell. I was so sick and tired of the bombing during the Korean War that I felt nauseated even when I just heard the sound of airplanes. I witnessed bombings several times in a day even, and I had to live my daily life trembling due to the fear of death.' Chinke Kim, who also lived in Pyŏngyang during the war, said, 'I was so infuriated by the indiscriminate bombing. I was even eager to meet with and ask the United States pilots the reason for the indiscriminate attacks ... Because numerous civilians were massacred as a result of indiscriminate bombing, North Koreans ground their teeth with extreme hatred towards the US soldiers.' 80

A 39-year-old woman and a 37-year-old man who were interviewed by Chinung Kang stated that the most insulting words in North Korea is 'mije sŭngnyangyi [American Imperialist Wild Dogs]'. The 37-year-

${ }^{78}$ Chaepong, Lee (1998), Panmichuŭi yŏnkuhakcha ŭi pukhan Sinch’ŏn pangmulkwan kwallamki [An essay of Sinch'ŏn Museum by the researcher who studies anti-Americanism], Mal (December), p. 155 .

${ }^{79}$ Chinung, Kang (2010), Pukhan ŭi kukka kwollyŏke taehan misichŏk chŏpkŭn: Hochŏnchŏk minchokchuŭi wa chumintŭl ŭi sam [Microscopic approach towards the state power of North Korea: Belligerent nationalism and the life of people], Hankuksahwaehak [Korean Sociology], 44(2), pp. 167, 170.

${ }^{80}$ Chinmok, Park (1983), Minch'o [Grass-root People], Wonŭm, Seoul, p. 250; Ungkyo, Kim (1993), Choguk [Homeland], P'ulbit, Seoul, pp. 184-185. 
old man said, 'American soldiers were described as a two-legged beasts, evil murderers and vicious bloodsuckers that made our people colonial slaves.' The 39-year-old woman, looking back on her childhood, said that whenever she had been involved in fights with friends, she had to listen to her mother's lecture comparing them to the 'American Imperialist Wild Dogs'. In North Korea, anti-Americanism was used as a means of the daily regulation of people from their childhoods. In addition, most North Korean defectors mentioned the game of 'hitting the Americans' which they played in kindergarten and primary school. A 45-year-old man confessed, 'I developed a radical anti-American view through the competitive physical games. ${ }^{, 81}$

A State of Mind, a British documentary film released in 2004, indirectly shows how anti-Americanism spread in the daily lives of North Koreans. The film is about the lives of two girls mobilized at a mass game practice in Pyŏngyang in 2003. Daniel Gordon, the director of this film, was the first foreigner to shoot a film without any restrictions imposed by the North Koreans. He did not face any interference regarding the editing of the film, either. In this documentary, we can witness the extreme poverty of people living in villages on the outskirts of Pyŏngyang. However, there are some scenes in this film that appear to be quite strange to the eyes of outsiders. The film shows the North Korean residents routinely and naturally participating in air defence training sessions, which still take place frequently without any notice, even at the present time. When they hear a siren through the speakers they must install in their homes, North Korean residents move to the designated shelters, having quickly turned off all the lights in their homes. In addition, girls take classes about the aggressive policies of the United States at school. Over the weekend, girls and their parents visit a museum exhibiting bombs dropped by the United States Air Force during the Korean War and once again engrave anti-Americanism in their hearts. It is rather shocking to outsiders that these are the ordinary everyday lives of North Koreans, not in the $195^{\circ}$ s, but today in the twentyfirst century. The dishonourable stigma of 'warmonger' given to the United States was in place even before the Korean War was accepted as an undeniable fact by the people of North Korea through historical experiences of the Korean War, and it is still contributing to the routinization of anti-Americanism in North Korea to this day.

${ }^{81}$ Ibid., pp. $170-171$. 


\section{Conclusion}

The majority of North Korean people hold very harsh antiAmerican sentiments that continue to this day. As we can see from the statements of North Korean defectors that the most offensive profanity in contemporary North Korea is 'mije süngnyangyi [American Imperialist Wild Dog]', anti-Americanism has become firmly entrenched in the hearts of North Koreans. There is a historical context with complex experiences from the Korean War that continue to influence the systemization and routinization of anti-Americanism in North Korea.

From the late nineteenth century to the first half of the twentieth century, the general image of the United States was positive in Korea. In addition, residents in the northern regions in the Korean peninsula, who are the main subjects of this study, were the most faithful Christians and pro-American people in all of Korea. The concept of 'American imperialist warmonger', promoted by the Soviet Union and North Korean leadership, did not find much of a reception among North Korean people in the early years of the Cold War $\left(1947^{-5}\right.$ ). The negative image of the United States during this time was merely a perplexing stigma which lacked substantiated grounds. However, the Korean War reversed all the historical context in a very short time.

As soon as the war broke out, the United States very quickly and aggressively intervened. The North Korean government persistently argued that the United States armed forces indiscriminately attacked and killed a lot of Korean civilians through aerial bombings, mass slaughters, sexual assaults, arson attacks, and germ warfare. In fact, most people in North Korea experienced these kinds of inhumane military attacks. Almost all North Koreans suffered immense personal loss — of their neighbours, friends, and family members. As a result, the North Korean government rode the bandwagon and promoted a fear of war, which spread among the people in North Korea, by launching aggressive anti-American propaganda. Various reports, statements, and newspaper articles described and highlighted the atrocities of the United States in no uncertain terms. Anti-American sentiment began to settle in the heart of North Korean people regardless of the truth of the atrocities.

Various kinds of anti-American movements continue to appear around the world. Such movements spread rapidly and disappear just as quickly in large numbers. This is due to many factors, including the United States military, globalization, and Islamic fundamentalism. 
Therefore, prudentially trying to approach the origins of such intense sentiments is one of the most important tasks to achieving peace throughout the world.

In the case of North Korea, deep anti-Americanism was formed by the unique historical context and subsequent experiences of North Koreans during the Korean War. Following the war, the North Korean government made a concerted effort to expand anti-Americanism to every corner of the country. Nowadays, anti-Americanism has become one of the most important ideologies that regulate the daily lives of the North Korean people. It is so ardent that it will be very hard to alleviate the intense sentiment in a short time by simple diplomatic means. Perhaps, only sincere 'ardor for reconciliation' ${ }^{\text {'2 }}$ and ardour for peace can offer shortcuts to the relaxation of anti-Americanism in North Korea.

${ }^{82}$ Wada Haruki, an eminent Japanese historian, insisted that 'ardor for reconciliation' is the most important and basic factor in designing a new peaceful world order. Since the 1980 s, he has continuously insisted that building a 'North-eastern Asian Co-operative House' can serve as the foundation of world peace. Wada, Haruki and Kijung, Nam (2014), Yut'op'iarosŏ chiyŏkchuŭiwa yŏksagaŭi immu [Regionalism as a utopia and the mission of historians], Yǒksa bip’yŏng [Critical Review of History], 109, pp. 220-221. 